DOI https://doi.org/10.30525/978-9934-588-90-7-16

\title{
ТЕКСТ І ДИСКУРС У ПЛОЩИНІ ЛІНГВІСТИКИ ТА ЛІТЕРАТУРОЗНАВСТВА
}

\author{
Бойко В. В. \\ кандидат філологічних наук, \\ старший викладач кафедри зарубіжної літератури та основ риторики \\ Комунальний заклад вищої освіти \\ «Вінницький гуманітарно-педагогічний коледж» \\ м. Вінниця, Україна
}

У сучасній лінгвістиці використовують термін «дискурс» і термін «текст», що спричинило ряд дискусій із проблем тексту-дискурсу. Ці дискусії спонукають відокремити чи прирівняти ці поняття, а також чітку характеристуки.

Філологія як наука гуманітарна допускає множинність визначень того самого поняття. У сучасній лінгвістиці вирізняється три основні підходи до вирішення термінологічної проблеми: утотожнення понять текст i дискурс, повне розмежування понять за характеристикою статика об'єкта (текст) /динаміка комунікації (дискурс) і залучення тексту до поняття дискурсу.

Визначення поняття «дискурс». Останнім часом усе частіше у більшості лінгвістичних публікацій вживається термін «дискурс».

Ретельне вивчення наукових джерел 3 окресленої проблеми засвідчило: на теренах науки за останні роки з'явилася низка праць, в яких їх автори:

1) визначають поняття тексту, дискурсу (В. Андреева, Р. Барт, Ф. Бацевич, Л. Новиков);

2) окреслюють коло загальних питань дискурсу (В. Карасик, М. Кожина);

3) вивчають проблеми тексту в лінгвістиці, філології та інших гуманітарних науках (М. Бахтін, В. Різун);

4) описують дискурс як когнітивно-комунікативний феномен (Л. Безугла, Є. Бондаренко, П. Донець);

5) актуалізують питання кореляції понять «дискурс» і «текст» (Н. Вовк, О. Єрофеєва, В. Чернявская). Натомість відсутні розвідки, в яких водночас зіставлялися б поняття тексту та дискурсу.

У широкому сенсі визначення «дискурс» запропонував Т. ван Дейк - як комплексну комунікативну подію, що відбувається між тими, хто говорить 
і слухає в процесі комунікативної дії в певному часовому, просторовому та іншому контексті. Така комунікативна дія може бути мовною, письмовою, мати вербальні й невербальні складники. Дискурс у вузькому сенсі - текст або розмова, що має здебільшого тільки вербальний складник - «текст» або «розмову». Дискурс у найзагальнішому розумінні - це «вербальний продукт комунікативної дії» [8, с. 5].

Р. Дж. Уотса текстову організацію дискурсу класифікує так:

1) культурний артефакт, що є продуктом діяльності великої кількості семіотичних систем, серед яких домінує мовна, й у ній генерується текст, а важливою другорядною;

2) частина гри в комунікативну діяльність між як мінімум двома комунікативними партнерами, які не $є$ фізично наявними водночас у комунікативній ситуації;

3) як мінімум два комунікативні акти за участю як мінімум двох комунікативних партнерів, один 3 яких (а саме акт читання) не $\epsilon$ примітивним генеруванням реальних мовленнєвих актів;

4) набір мовленнєвих актів, генерований як ілокутивні акти з набором конвенціонально визначених ілокутивних сил;

5) реалізація набору екстралінгвістичних припущень, які роблять комунікативні партнери (індивідуальні набори припущень серед комунікативних партнерів можуть бути дуже схожими або відрізнятися; вони ніколи не бувають абсолютно ідентичними);

6) розвиток теми, який, залежно від довжини та типу тексту, складається $з$ певної кількості текстових одиниць, що організуються в текстову структуру відповідно до правил компонентної побудови тексту (тип текстових одиниць та їх розміщення в структурі тексту характеризує комунікативний тип письмового тексту);

7) мовленнєві дії комунікативних партнерів, які мають ідіолектні варіанти лінгвістичної системи, вибраної для комунікації [8, с. 7].

К. Серажим розглядає дискурс як взаємодію трьох структур: структуру мисленнєвих процесів мовця; мовної структури і структури мовленнсвої ситуації (відношень між мовцем та адресатом) [7, с. 13]. Так, погоджуюсь із дослідницею, яка виділяє п'ять основних значень «дискурс»:

1) зв'язний текст у сукупності з екстралінгвістичними чинниками;

2) текст, узятий у подієвому аспекті; мовлення як цілеспрямована соціальна дія, як компонент, що бере участь у взаємодії людей;

3) текст, що утворився в процесі дискусії, коли значення «на виході» стає адекватним авторському задуму (на думку авторки, в такому трактуванні дискурс $є$ ментальним утворенням); 
4) сукупність тематично, культурно або інакше пов'язаних текстів, що допускає розвиток доповнення іншими текстами;

5) спілкування, що розглядається як реалізація певних дискурсивних практик.

Донині існує проблема визначення поняття «текст». Зауважу, що текст як лінгвістичний феномен надзвичайно багатопланове явище, i це зумовлює множинність його дефініцій. Так, беручи до уваги структурносемантичний niдxод, текст виступає як упорядкована структурно-змістова єдність, що об'єднана різними типами лексичного, логічного, лексикограматичного зв'язку. 3 позицій комунікативного напрямку текст характеризується як деяка система комунікативних елементів, функційно (тобто для конкретних цілей) об'єднаних загальною концепцією або комунікативною інтенцією в єдину замкнуту ієрархічну структуру. Враховуючи параметри комунікативної ситуаиії: адресат, адресант, код, повідомлення, обставини, будь-який текст - це смислове ціле, таке, що $є$ організованою єдністю складових його елементів; повідомлення автора (адресанта) читачеві (адресатові) [3, с. 87]. Наведені визначення в загальних рисах відображають суть тексту. І. В. Арнольд заувазує, щоб дати загальне визначення тексту, яке б відрізняло його від інших рівнів мови, необхідно дати відповідь на такі питання:

1) що є констатувальним чинником тексту;

2) які межі тексту;

3) якими можуть бути розміри тексту й чим вони визначаються; 4) які зв'язки тексту й інших рівнів мови [4, с. 24]. Спробуємо означити складові тексту:

1) Текст призначений не тільки для передавання, але й для зберігання інформації.

2) Межі тексту визначаються задумом автора й у письмовому тексті зображуються графічно.

3) Для того, аби відрізняти текст від нетексту обсяг повідомлення до уваги брати не варто.

«Текст - первісна даність (реальність) і вихідна точка кожної гуманітарної дисципліни» [5, с. 34], котра, розглядає його як знакове, творче ціле, втілення складної і багатопланової системи відносин. Текст - це багатогранне, багатоаспектне явище, що має, без сумніву, свою специфіку, яка полягає у тому, що його потрібно розглядати 3 урахуванням різних підходів. Текст як найскладніший об'єкт філології можна досліджувати в різноманітних ракурсах: онтологічному (сутність тексту як лінгвістичної реальності, його статус та специфіка серед інших мовних одиниць); гносеологічному (відображення об'єктивної дійсності, 
а точніше, знань про духовну і матеріальну культуру); прагматичному (ставлення автора до змістового матеріалу тексту); лінгвістичному (мовне оформлення знань: внутрішньотекстова структура та семантика мовних одиниць).

Виходячи з викладеного, при будь-якому підході до розгляду терміна «дискурс» мова йде про характер його взаємин з лінгвістичним поняттям «текст».

Не можна не погодитися з I. Руберто, який виокремлює три основних підходи до вирішення термінологічної проблеми «текст - дискурс»:

- ототожнення обох понять;

- повне їх розмежування по параметру «статика об'єкта» (текст) / «динаміка комунікації» (дискурс);

1) включення тексту в поняття дискурсу [2, с. 23]. Андреева В. також визначає існування трьох, але інших варіантів тлумачень характеру взаємовідносин понять «текст» і «дискурс». Він вважає, що:

2) текст - спосіб передачі інформації, дискурс - генератор сенсу;

3) дискурс - спосіб передачі інформації, текст - генератор сенсу;

4) дискурс - текст у розвитку [1, с. 24-27].

Що стосується розгляду проблеми ідентифікації понять «текст» $\mathrm{i}$ «дискурс», то, на думку М. Кожиної, воно стало можливим у зв'язку з появою лінгвістики тексту: саме тоді номінація «дискурс» починає використовуватися паралельно 3 терміном «текст», проте, дослідник зазначає, що дискурси - це не тільки тексти [4, с. 21].

Отже, під дискурсом варто розуміти текст зв'язного мовлення, який складається 3 послідовності комунікативних одиниць мови, що переважають за обсягом просте речення, і перебувають у смисловому зв'язку, вираженому лінгвістичними засобами. Під текстом - переважно абстрактну, формальну конструкцію. Дискурс - різні види іiі актуалізації, які розглядають під кутом зору ментальних процесів і у зв'язку 3 позалінгвальними факторами. Е. Бенвеніст одним з перших надав слову дискурс, яке у французькій лінгвістичній традиції означало мовлення взагалі, текст, термінологічного значення, позначивши ним «мовлення, привласнюване мовцем» [3, с. 36-137].

\section{Література:}

1. Андреева В. А. Литературный нарратив: дискурс и текст. Норма. Київ, 2006. 182 с.

2. Бехта 2004, Бехта I. А. Дискурс наратора в англомовній художній прозі. Київ: Грамота, 2004. 304 с. 
3. Бондаренко А. I. Художній дискурс в інтерпретаційному вимірі: лінгвостилістичний аспект. Ніжин, 2008. 226 с.

4. Бурбело В. Б. Художній дискурс в історії французької мови та літератури: автореф. дис. на здобуття наук: спец. ступеня доктора філол. наук: 10.02.05 / Київ,1999. 42 с.

5. Вецкур Т. А. Текст та дискурс: проблеми диференціації. Актуальні проблеми філологї та перекладознавства. Хмельницький, $2005.73 \mathrm{c}$.

6. Демьянков В. Текст и дискурс как термины и как слова обыденного язика: підручник. Запоріжжя: Прем’єр, 2008. 332 с. - Режим доступу http://www.infolex.ru

7. Приходько А. М. Концепти і концептосистеми в когнітивнодискурсивній парадигмі лінгвістики, Запоріжжя. 2008. 332 с.

8. Шевченко I. С. Когнітивно-комунікативна парадигма i аналіз дискурсу. Дискурс як когнітивно- комунікативний феномен. Харків, 2005. C. 9-20.

DOI https://doi.org/10.30525/978-9934-588-90-7-17

\section{ПРОБЛЕМА ЕВОЛЮЦЇ̈ ПАТРІОТА В КОНТЕКСТІ ВІЙНИ НА СХОДІ УКРАЇНИ (НА МАТЕРІАЛІ РОМАНІВ С. ЖАДАНА «ВОРОШИЛОВОГРАД» ТА «ІНТЕРНАТ»)}

Волосянко I. В. аспірантка

Прикарпатський національний університет імені Василя Стефаника, викладачка кафедри перекладу та філології

Приватний вищий навчальний заклад Університет Короля Данила м. Івано-Франківськ, Украӥна

Тема війни вже неодноразово була центром зацікавлень та досліджень як науковців, так і письменників. Саме у процесі еволюції і становлення людство віками тягнуло за собою шлейф міжусобиць, а митці за допомогою метафорики, сюжетних колізій у рефлексивній формі відтворювали ті чи інші події. Незважаючи на те, що війна, здавалося б, мала залишитися в минулому, у своїй сув'язі зі смертю та деструкцією вона повернулася сьогодні в реальне життя людей, а, відповідно, й на сторінки художньої літератури. 